\title{
Moralsk kasuistikk i politiarbeid
}

\author{
Jens Erik Paulsen \\ Politihøgskolen
}

Kontakt: jenpau@phs.no

\section{Sammendrag}

Politiarbeid styres av lover og regler, prosedyrer og i noen grad «tiltakskort» for enkelte situasjoner. Likevel befinner politibetjenter seg relativt ofte i situasjoner som er moralsk sett krevende og der veiledningen er sparsommelig. Norsk politi har nokså vid adgang til å utøve skjønn, og det eksisterer et uttalt ønske om å styrke den moralske refleksjonen og beredskapen systematisk. I denne artikkelen undersøkes styrker og svakheter ved å benytte kasuistisk metode for å håndtere moralske konflikter i politipraksis, basert på sentrale bidrag fra forskningslitteraturen omkring dette temaet. I beskrivelsen av kasuistisk metodikk beskrives den praktiske og teoretiske kompetansen som kreves for bruken og dannelsen av såkalte paradigmer. Selv om dannelsen av paradigmer i noen grad kan sies å begrense betjentenes rom for skjønnsutøvelse, konkluderer artikkelen med at dette oppveies ved at metoden gir en høyere grad av profesjonalitet, forutsigbarhet og yrkesetisk kompetanse i politietaten. Selve det kasuistiske arbeidet bidrar dessuten til å gi tjenestepersonene et bredere syn på moralsk krevende situasjoner.

Emneord: Etikk, erfaringslæring, kasuistikk, politiarbeid, profesjonalisme 


\section{Introduksjon}

I politikulturen florerer muntlige fortellinger som eksemplifiserer imponerende politiarbeid, hva som er «godt nok» politiarbeid, og hva man bør passe seg for. Slike fortellinger er en del av det som kalles pikettkulturen ${ }^{i}$ i politiet, og er viktig for den yrkesmessige identitetsskapingen. Som Hulst (2013) påpeker beror fortellingenes funksjon dels på hvem som forteller og i hvilken sammenheng dette skjer. Uansett påvirker fortellingene måten man tenker om yrkespraksis. Systematisk arbeid med fortellinger skjer imidlertid i mindre grad, selv om behovet for systematisk refleksjon over virksomheten er anerkjent. Ifølge Politianalysen (NOU 2013: 9, s. 21) mangler politietaten «...gode systemer for å lære, utvikle og forbedre virksomheten systematisk. Det finnes mye god kompetanse, mange meget dyktige og kompetente miljøer, men utvalget ser en begrenset grad av systematisk erfaringslæring, analyse og utvikling av beste praksis.»

Noen åpenbare unntak nyanserer dette bildet: På den ene siden politiets eget klagebehandlingssystem som gir ut årlige rapporter som kategoriserer og eksemplifiserer mottatte klager på tjenestehandlingerii. På den andre siden den uavhengige Spesialenheten for politisaker som behandler anmeldelser mot ansatte i politi og påtalemyndighet, og som publiserer årsrapporter som redegjør for de vurderinger som gjøres. Spesialenheten trekker altså grenser for hva som regnes som straffbart. Eksemplene som trekkes frem i disse kildene kan sies å utgjøre en form for det vi her kaller «moralsk kasuistikk», men da typisk i negativ forstand - dette bør ikke skje, eller, dette er uheldig, men ikke straffbar praksis. I tillegg evalueres også større enkeltstående hendelser bredt, gjerne i grupper sammensatt av politiets egne spesialister og eksterne representanter.

Et av politireformens såkalte effektmål er å skape et politi som «deler kunnskap og lærer av erfaringer» i større grad. Justis- og beredskapsdepartementet presiserer dette ved å si at «...[k]unnskapsdeling, evaluering og læring skal skje systematisk og være en naturlig del av arbeidsformen i politiet» (Justis- og beredskapsdepartementet, 2016). Kasuistikk er et godt rammeverk for systematisk erfaringslæring fordi den gjør det mulig å diskutere moralsk ladde problemstillinger på en komparativ og saklig måte.

Hensikten med denne artikkelen er å beskrive moralsk kasuistikk som metode og hvordan den kan anvendes som del av politiets yrkespraksis. I tillegg diskuteres praktiske problemer ved anvendelsen, samt noen generelle innvendinger mot kasuistikk.

\section{Hva er moralsk kasuistikk?}

Når vi vurderer hva vi bør gjøre (og ikke gjøre), bedriver vi etisk refleksjon. I etikken som fag er refleksjonen gjerne metodisk. Kasuistikken er en slik metode der kasus eller praksiseksempler både er utgangspunkt og rettesnor.

Begrepet kasus virker kanskje gammeldags. I dag brukes ofte det engelske «case» i stedet når man refererer til eksempler fra praksis ${ }^{\mathrm{iii}}$. Noen case demonstrerer hvordan situasjoner er blitt håndtert på eksemplarisk vis. I denne teksten kalles slike mønstereksempler for «paradigmer $\rangle^{\text {iv }}$. Paradigmer minner om det Liv Finstad i Politiblikket kaller for «modeller» for godt politiarbeid". Praksisfortellingene om disse har en normativ funksjon: Slik bør yrket utøves! Ikke alle paradigmer 
beskriver imponerende tjenestehandlinger under ekstreme forhold. Som nevnt, gir noen simpelthen eksempler på hva som i hverdagen er «godt nok» politiarbeid, og illustrerer et kompetansenivå som de fleste yrkesutøvere burde kunne leve opp til. En tredje type paradigmer gir eksempler på hvor ille det kan gå, altså avskrekkende eksempler, hvis man opptrer slik eller slik. Sistnevnte type danner norm utfra at de utgjør uformelle forbud. ${ }^{\mathrm{vi}}$

Case gir altså føringer i form av inspirasjon, anbefalinger eller forbud for yrkesutøvelsen. Som metode dreier moralsk kasuistikk seg både om å utarbeide slike case, samt aktivt å orientere seg etter disse når man havner i situasjoner som innebærer moralsk konflikt (Strong, 2013). I yrkesutøvelsen kan man altså søke støtte i paradigmatiske eksempler som, helt eller delvis, gir veiledning for saker man er usikre på. Et paradigme danner mønster for et problem man står overfor - såfremt de to er like nok. Hva «lik nok» innebærer er en viktig diskusjon i kasuistikken.

Kasuistikken er slik praksisnær, den representerer en tankemåte som minner om den erfaringslæringen som skjer mer eller mindre automatisk, spesielt på noenlunde oversiktlige eller det Kirkebøen (2013, s. 390) kaller «vennlige» områder av yrkesutøvelsen. Men i kasuistikken er det ikke den enkeltes subjektive erfaring som setter standard. Som metode for et yrkesfellesskap må kasuistikken være et samarbeid som munner ut i en rimelig grad av konsensus rundt paradigmene. I praktisk anvendelse kan selvsagt meningene ofte avvike yrkesutøvere imellom. Situasjonsforståelsen kan være ulik, og et paradigme er ikke nødvendigvis helt dekkende for situasjonen. Spørsmål som: «Kan flere paradigmer være relevante for en og samme situasjon?», og «Hvor generelle kan paradigmer være?», melder seg fort.

Dette er spørsmål som diskuteres i faglitteraturen. Man snakker dels om streng (hard core) kasuistikk der man kun bedømmer én enkelt sak i forhold til én annen enkeltsak, og der begge er presise autentiske tilfeller - såkalt sak-til-sak-kasuistikk. En moderat (soft core) form for kasuistikk er vanligere og der fungerer paradigmer som konkretiseringer av «beste praksiser» som er såpass generelle at de danner mønster for en hel klasse med [tjeneste]handlinger (Arras, 2017, s. 52 f.). Kan etiske prinsipper fungere som paradigmer, og kan man eventuelt ha flere paradigmer som adresserer omtrent samme situasjon? I en moderat versjon synes dette å være tillatt. Spielthenner (2016, s. 419n415) oppsummerer dette slik:

There are, however, different strains of casuistry. While moderate versions allow the use of principles and ethical theories, there are also strongly particularistic strains that reject principles and attempt to move directly from one particular case to another. Some authors distinguish between casuistry that employs only one precedent case ('single-paradigm casuistry') and versions that use more prior cases ('multiple-paradigm casuistry'), and some writers take the term 'casuistry' in a very broad sense to refer to a detailed discussion of specific cases or moral problems with the aim of finding a justifiable decision.

I det følgende legges en moderat variant til grunn, ikke bare på grunn av dens praktiske anvendelighet, men også fordi politiarbeid er nødt til å forholde seg til lovverk og politisk nedfelte prinsipper i stor utstrekning. Lokale forhold må også tas i betraktning. F.eks. kan en modell som representerer optimal oppdragsløsning i Oslo være feilslått på Skjervøy, ettersom demografien og politiets ressurstilgang er ulike. Paradigmer synes slik å ha et gyldighetsområde, og flere varianter av paradigmet kan være nødvendige for å forklare beste praksis på et problemfelt. Et slikt bredt paradigme 
bør imidlertid ha stor grad av konsistens for å gi mening som paradigme. Gitt at en slik konsistens finnes, kan også en bred form for kasuistikk bidra til forutsigbarhet, rettferdighet og etterrettelighet.

Selv om kasuistikken er praksisnær og i utgangspunktet knyttet til erfaringer, er det noen sentrale begreper man bør kjenne til: For det første, paradigmer som er betegnelsen på anerkjente mønstre; for det annet, «test-caser» som er saker som man vurderer opp mot paradigmene. Disse benevnes problemer i denne artikkelen. Når man skal finne aktuelle paradigmer, vurderer man først hvilken type problem man har foran seg. I politiarbeid gir det f. eks ikke alltid seg selv om et problem ligger i «straffesporet» eller i «forebyggingssporet». Er det hjelp eller kontroll man bør sikte mot? Denne innledende klassifiseringsprosessen kalles å vurdere problemets taksonomi, eller moralske kontekst. Finner man et paradigme som er innenfor samme taksonomi som problemet, vurderer man deres likheter og forskjeller. Er likheten stor nok, foretar man en analogislutning, det vil si å følge paradigmets beslutning. Denne tankemåten hviler på det aristoteliske prinsippet om likebehandling som tilsier at like saker skal behandles likt med mindre det finnes relevante forskjeller mellom dem (Kvalnes, 2012, s. 24). Hvis det finnes relevante forskjeller mellom problemet og paradigmet kan man enten lete etter et mer egnet paradigme, eller justere paradigmets handlingsforslag slik at det passer bedre i den situasjonen man står i. Eventuelt kan man argumentere for dannelsen av et nytt paradigme som er dekkende for problemet. ${ }^{\mathrm{vii}}$

Kasuistikken er altså ingen «svart boks» som genererer løsninger, men en metodisk måte å nærme seg moralske problemer på som krever kjennskap til paradigmene og aktive vurderinger i form av sammenligning av saker.

\section{Moralsk kasuistikk i praksis}

Moralsk kasuistikk innebærer som sagt å la seg rettlede av paradigmer i moralsk krevende situasjoner. Da er det viktig at paradigmet og problemet er innenfor samme taksonomi, og at de to er like nok til at man kan dra analoge slutninger. Hva vil det så si å være «like nok»? I moralsk kasuistikk innebærer det at problemet inneholder omtrent de samme moralske hensynene (eller verdiene) som paradigmet. Hvis sakene synes å ha samme moralske struktur, selv om de på overflaten synes svært ulike, kan man vurdere om strukturen gir grunnlag for analoge overveielser og tjenestehandlinger. Taksonomispørsmålet er viktig å ta i betraktning, for saker som synes like kan være problematiske å sammenligne hvis paradigmet dreier seg om en straffesak, mens problemet er av kriminalitetsforebyggende karakter. For eksempel er det forskjell på politiets adgang til å benytte informasjon gitt i formelle avhør og informasjon gitt i bekymringssamtaler. Taksonomien kan også endre seg ved endret lovgivning. F.eks. er det typer «innganger» (les: måter å få adgang til å ransake) som nærmest var paradigmatiske tidligere, men som i dag er uakseptable, ettersom loven tolkes annerledes eller hjemlene er blitt endret. ${ }^{\text {viii }}$

Av ulike grunner kan det være problematisk å identifisere klare og tydelige paradigmer for politiarbeid. Det er likefullt mulig å argumentere for at noen eksempler på handlemåter fortjener status som paradigmer. For å begynne et sted: i Paulsen (2020) vises til et eksempel der en kollega stanses i en trafikkontroll og der tre gjennomsnittsmålinger i 80 -sonen gjøres: den første viser $97 \mathrm{~km} / \mathrm{t}$ (hvilket gir to prikker i førerkortet), den andre er på $115 \mathrm{~km} / \mathrm{t}$ (tre prikker) og den siste er på 120 
$\mathrm{km} / \mathrm{t}$ (beslag av førerkort). Patruljen tilkjennegir seg med blålys og råkjøreren senker farten og stanser på første egnede sted. Det viser seg å være en nyansatt kollega som stanses. En verdibasert refleksjon argumenterer for følgende paradigmatiske respons i denne saken:

Paradigme: En patrulje stanser en kollega etter tre (stigende) fartsmålinger over fartsgrensen. Saken berører i tillegg til de nevnte parter også øvrige trafikanter og publikum generelt. Rettferdighet, kollegasolidaritet, åpenhet og trygghet anses som sentrale verdikriterier. $\AA$ gi en reaksjon $\mathrm{i}$ henhold til den laveste målingen ivaretar kun én av verdiene. Alternativt kunne man gått for den midterste målingen og irettesatt kollegaen strengt, men etter en intensjon- og konsekvensvurdering vurderes det å legge høyeste måling til grunn på en saklig og ivaretagende måte, som det optimale. Denne handlingen er rettferdig, trygghetsskapende og solidarisk (sistnevnte gjennom handlemåten). Offentlighet omkring avgjørelsen er uproblematisk.

Selv om det er rom for ulike meninger om vurderingen, la oss for eksemplets skyld tenke at den bredt anerkjennes som paradigmatisk. Hvordan kan dette paradigmet anvendes?

Problem 1: Sett at en politistudent, på sin første vakt i praksisdelen av studiet, stanser en bil som har omtrent samme kjøremønster som nevnt ovenfor. Dette synes som en sak som deler taksonomi med paradigmet. Studenten mener også at de moralske egenskapene til hans sak er nokså sammenfallende med paradigmets. Analogt bør da problemet ha samme slags løsning som paradigmet. Studenten er ikke i tvil om at førerkortet bør beslaglegges, selv om sjåføren viser seg å være politimesteren som ser strengt på studenten. Fortsatt trygg i sin sak beslaglegger studenten førerkortet til politimesteren.

Studenten kunne selvsagt påpekt at det er minst én vesentlig forskjell mellom dette problemet og paradigmet, nemlig at betjenten i paradigmet hadde fast jobb og dermed oppsigelsesvern. Som student risikerer han å havne i unåde og ikke få jobb etter endt utdannelse. På den andre side: hvis paradigmet er kjent og anerkjent ved tjenestestedet, vil det også kunne ses på som en svakhet om studenten $i k k e$ følger det - selv som student. Her hadde studenten faktisk sjansen til å demonstrere sin integritet! For studenten vil nok dette likevel oppleves som et sjansespill, der moralske hensyn som autoritet og lojalitet klart gjør studenten mer sårbar enn den fast ansatte betjenten i paradigmet. $^{\text {ix }}$

Problem 2: Her tenker vi oss samme omstendigheter som foregående, men nå er det ikke politimesteren studenten stanser, men sin egen farfar som er helt avhengig av bil for å besøke farmor som er på sykehus. Studenten ser at dette er en sak som kan være innenfor paradigmets taksonomi. Situasjonen synes derfor analog, men beslag vil antagelig påvirke studentens relasjon til familien, og familien befinner seg jo i øyeblikket i en spesielt sårbar situasjon. Studenten går derfor tilbake for å konsultere med veileder, og sier at han er klar over hva paradigmet og politirollen krever. Likevel sier studenten at et annet paradigme er mer passende, nemlig et som tilsier at man ikke har vitneplikt i forhold til et familiemedlem (Straffeprosessloven, § 122). Det finnes et habilitetsforhold som gjør at det for ham er en moralsk relevant forskjell mellom paradigmet og saken han står i. Problemet involverer slik flere moralske hensyn enn det opprinnelige paradigmet, og studenten synes at det vil være urimelig å trekke en analog slutning.

Når det gjelder appellen til straffeprosessloven $\S 122$ (JD, 1986), kan man forstå hva studenten mener, men studenten er neppe å regne for et vitne i en rettssak her, og § 122 tilhører slik en annen taksonomi. Det virker derimot ikke helt urimelig å påstå at et habilitetsparadigme, for eksempel der 
en etterforsker slipper å etterforske et familiemedlem, kunne ha relevans. Hvis løsningen i begge tilfeller innebærer at en annen betjent håndterer situasjonen (hvis dette er mulig), så synes dette som en paradigmatisk løsning som også ivaretar et spesielt menneskelig hensyn. Saken blir da fortsatt behandlet i tråd med det opprinnelige paradigmet. Den eneste forskjellen er at man tar hensyn til en tilfeldig kvalitet ved saken. Her ser vi et eksempel på at et problem både kan forholde seg til flere paradigmer, og hvordan man kan arbeide for å opprettholde paradigmet.

Problem 3: Politiet tilkalles etter at en ung mann har forsøkt å bruke annen manns legitimasjon på et utested. En politistudent håndterer saken. Den unge mannen fremstår rolig og saklig og konstaterer tørt at dette nok kommer til å få store konsekvenser for fremtiden hans i Forsvaret. En anmeldelse kan være nok til å stenge noen dører, og politistudenten vet innerst inne at hun selv også for lenge siden har hatt fake legg, og at uflaks da kunne ført til at hun ikke hadde kommet inn på Politihøgskolen. Politistudenten blir litt i villrede, og velger å beslaglegge legitimasjonen samt bortvise den unge mannen fra sentrum, men altså ikke anmelde ham.

Kan Problem 3 sammenlignes med Paradigmet? Har sakene samme taksonomi? På overflaten synes trafikkontroll og falsk legitimasjon å være svært forskjellige. Men de har også likhetstrekk. Flere av de samme moralske hensynene synes å være til stede. Det er riktignok ikke kollegalojalitet eller slektsforhold det er snakk om, men det er en form for identifikasjon som skjer: studenten har gjort det samme selv og kjenner seg igjen. Like klart aktualiseres rettferdighet i form av likhet for loven her. Trygghet er kanskje ikke så aktuelt her som i paradigmet, der jo fartsovertredelsen klart utgjorde en fare for andre trafikanter. Men, vil man ha en dokumentforfalsker i Forsvaret, kanskje i en viktig posisjon? «Vil man det i politiet», spør studenten seg selv (og tenker at man kanskje ikke bør bruke seg selv som paradigmatisk forbilde). Den moralske strukturen til paradigmet og Problem 3 ligner noe, men er ikke identisk. Når er saker like nok? Her er det viktig å vurdere forskjeller og likheter grundig. For eksempel: hvordan er alvorlighetsgraden i de to casene? Er legitimasjonen stjålet eller fabrikkert? I hvilken grad går handlingen utover tredjeperson? Alder og historikk kan spille inn i vurderingen av likhet. Gjør det en forskjell om dette er en 16-åring med doktorert skolebevis eller en 40-åring med et stjålet pass? Spiller det f.eks. noen rolle hvor flat vedkommende legger seg i møtet med politiet, eller om dette er første gang vedkommende er i kontakt med politiet? Omstendigheter utgjør del av bildet, men det fjerner ikke det faktum at likhet for loven er et tungtveiende moment. Kanskje er det fornuftig å etablere flere varianter av paradigmet for slike situasjoner, for paradigmet er ment å skulle gi beslutningsstøtte og forutsigbarhet, ikke legitimere forskjellsbehandling og kreativitet. Avvik må kunne begrunnes.

Den moderate kasuistikeren vurderer altså hvilken taksonomi problemet tilhører og orienterer seg om hvilke paradigmatiske eksempler som gir veiledning for imponerende, greie eller skammelige måter å håndtere problematikken på. Da finner vedkommende forhåpentligvis et kontinuum å plassere saken i, blant akseptable løsninger. Men dette forutsetter et etablert og anerkjent sett av paradigmer. 


\section{Hvordan bli dyktig til kasuistikk?}

Den moralske kasuistikken gir et argument for likebehandling. ${ }^{\mathrm{x}}$ Likebehandling innebærer ikke nødvendigvis millimeterpresisjon, men at man som betjent forsøker å holde en linje, noe som bidrar til å skape forutsigbarhet for medborgerne. Kasuistikken bidrar til å etablere slike linjer gjennom å sammenligne de relevante moralske sidene ved saken. Det å kunne «skjelne» slike sider er en viktig del av skjønnsutøvelsen (Kleinig, 1996, s. 82) uttrykt ved den definisjonsmakten politibetjenter forvalter. Deretter sammenligner man med paradigmer som man er sikre på. Oversikt over paradigmene og kunnskap om deres egenskaper er dermed nødvendig for å lykkes.

Vi så i Problem 3 at studenten appellerte til § 122 som paradigme. Mer presist, kasuistisk sett, hadde det vært om studenten hadde sammenlignet med et paradigmatisk eksempel av $\S 122 \mathrm{i}$ bruk. Et godt paradigme bør nemlig gi nok illustrasjon av et problem til at dets taksonomi kan gjenkjennes. ${ }^{\mathrm{xi}}$

Med sine paradigmer og problemer i form av realistiske praksisfortellinger har kasuistisk metode en relativt lav terskel i forhold til andre typer anvendt etikk som trekker på abstrakte prinsipper eller fortolkning i lys av teoretiske konstruksjoner. Dette krever imidlertid en form for skriftliggjøring av paradigmer, både for å unngå misforståelser og for å ha et utgangspunkt for å skape bred konsensus. Gjennom skriftliggjøring kan også paradigmene utvikles, og sammenhenger mellom saker etableres, utdypes, kritiseres og modifiseres gjennom en bredt anlagt erfaringsdelingsprosess. Den som er dyktig i kasuistikk, kjenner paradigmene og kan bedømme likheter i strukturen og relevansen av ulikheter på en overbevisende måte (og følger ikke bare blindt andres autoritet på feltet).

Kasuistikken er ikke noen lettvint løsning man bør velge for å unngå tradisjonell etisk teori. Adekvat situasjonsforståelse krever erfaring, og i praksis kan de moralske hensynene være vanskelige å se mens arbeidet pågå. Man kan ha tunnelsyn på det rent operative, kanskje er stressnivået høyt, kanskje er man forutinntatt utfra erfaringen man har med de involverte partene, eller utfra oppdragsinformasjonen som forelå i forkant. Kanskje villedes man bevisst av f.eks. melder eller et vitne. Dette er momenter som kan gjøre den moralske situasjonsforståelsen krevende, og lede til at man bommer både på vurderingen av taksonomi og valg av paradigme. Så kasuistikken vil ofte heller ha karakter av kritisk-refleksivt arbeid. Man setter seg ned i etterkant for å vurdere gjennomføringen for slik, eventuelt, å forbedre paradigmet.

Det er videre nokså urealistisk at et komplekst moralsk problem skulle kunne beskrives av ett detaljert paradigme. I praksis ville man da være avhengige av at problem og paradigme var identiske. Dette er som vi har sett en meget streng måte å tenke kasuistikk på (sak-til-sak kasuistikk) som gjør kasuistikken lite anvendelig. I praksis opererer man snarere med et sett av paradigmatiske eksempler ${ }^{\mathrm{xi}}$, der man plasserer problemet $\mathrm{i}$ forhold til et kontinuum av paradigmer, mellom imponerende og ikke tillatte løsninger (Arras, 2017, s. 50). Et paradigme blir da en betegnelse på et (relativt smalt) spekter av løsninger. Den som er dyktig i kasuistisk metode kjenner til nyanser av paradigmet. Når man trekker analoge slutninger, plasserer man så problemet i paradigmespekteret, og påpeker likheter og forskjeller.

Gjennom å arbeide kasuistisk styrkes slik evnen til å skjelne og argumentere for moralsk relevante forskjeller og likheter, ikke bare fra sak til sak, men også mellom typer saker og klasser av paradigmer. Dette krever også at man utnytter både egen og andres praksiserfaring. Det er denne 
prosessen som skaper reell systematisk erfaringslæring. Kasuistikken som arbeidsform tjener jo nettopp til å artikulere kritiserbare innsikter som ellers ofte får lov til å være muntlige eller tause, og dermed relativt uangripelige. Gjennom å formulere og eksponere paradigmatisk praksis for kritikk, arbeider fellesskapet frem ressurser som kan være til støtte, også i akutte situasjoner. Utarbeidelsen av slike begrunnede paradigmer gjør fagfellesskapet potensielt i stand til å etablere kunnskap i sterkere forstand (Grimen, 2008; Smeby, 2013). Hvis begrunnelsene/paradigmene ikke bare skriftliggjøres, men også gjøres åpent tilgjengelige, vil politiarbeid dessuten også blir mer transparent for befolkningen.

\section{Tre utfordringer for moralsk kasuistikk}

I det følgende presenteres tre utfordringer i arbeidet med moralsk kasuistikk, nemlig hvordan status som paradigme etableres, hvordan likhet kan ligge til grunn for å trekke analoge slutninger, og i hvilken grad kasuistikken kan bidra til å sementere bestående praksiser.

\section{a) Hvordan får noe status som paradigme?}

Hvorfor får noen fortellinger og oppdragsløsninger status som paradigmatiske? Hvem bestemmer dette? Innenfor et yrkesfellesskap/profesjon vil det være vanskelig å peke på enkeltmennesker. Politiarbeid, for eksempel, formes av mange kilder. På den ene side politiske føringer og lovverk som f.eks. straffeprosessloven og politiloven. Videre kan nevnes utdanningen, Riksadvokatens skriv, Spesialenhetens uttalelser, samt trening av innsatspersonell på ulike nivåer. Slike faktorer påvirker og setter standarder, i likhet med uformelle kulturelle faktorer som arbeidsoppgavers prestisje, betjenters erfaringer, og tanker om hva politiets rolle egentlig er. Konkrete hendelser kan prege politiarbeid i etterkant ${ }^{\mathrm{xiii}}$ - folks forventninger til politiet, og endringer i demografien likeså. Lokalt, i yrkeshverdagen, vil ofte konkrete personer med stor grad av formell eller uformell makt påvirke hvordan tjenesten utøves ${ }^{\text {xiv }}$.

For politistudentene i Problem 1-3 vil typisk praksisveilederen være den som bidrar med mønstrene for hvordan ting skal gjøres, selv om studenten etter hvert orienterer seg bredere og selv gjør seg erfaringer på godt og vondt. Men studentene setter sjelden standard i etaten. Politietaten er hierarkisk: en veileder, eller en annen overordnet, kan beordre både hva som skal gjøres og hvordan dette skal gjøres. Så spørsmålet om definisjonsmakt melder seg med full tyngde. Hvem «setter» paradigmene? Er det personen med formell autoritet på arbeidsstedet, eller er det uformelle ledere som setter standarden? Er det flertallet av de erfarne som bestemmer, eller er det på en eller annen måte flertallet av alle de operativt ansatte? ${ }^{\mathrm{xv}}$ Mange mønstergyldige måter å handle på vil være nedfelte i tause og åpne praksiser på arbeidsstedet. Blind yrkessosialisering i forhold til slike kan klart utgjøre en utfordring for opprettholdelsen av en saklig, åpen og fleksibel moralsk kasuistikk. Skal arbeidet med moralsk kasuistikk oppnå den bredden som er nødvendig, må en grad av herredømmefrihet (Habermas, 1987) etableres.

I hverdagslige «godt nok»-eksempler ligger kanskje bare en slags «allmennmoral» til grunn: man gjør som man pleier, man handler på en måte som det ikke reageres på, bruker ikke for mye 
makt, men heller ikke for lite. Man holder seg «innafor». Dette er hva Tranøy (1998) benevner «åpen konsensus», det vil si: det som det ikke reageres på i fellesskapet. I politiarbeid, som i andre yrkespraksiser, vil det finnes et vell av akseptable eller greie nok løsninger. Utfordringen er da at hverdags-paradigmene blir usynlige og slik kan uheldige praksiser eller middelmådighet sementeres. Også hverdagslige paradigmer bør skriftliggjøres og etterses.

Når det gjelder kritiske situasjoner, er klare rutiner avgjørende. Det samme burde gjelde i situasjoner der den «moralske intensiteten» (Carson, Kosberg, Skauge \& Laurberg, 2015, s. 43) er høy, f.eks. politiets interaksjon med spesielt sårbare personer, eller saker der ytringsfriheten står på spill - politiets forhold til Black Lives Matter-bevegelsen gir et relativt ferskt eksempel på begge to. Nye kriminalitetstrender kan også lett falle utenfor det som regnes som politiets oppgaver hvis paradigmene formuleres for snevert. I dag står f.eks. politiet i økende grad overfor mennesker med psykiatriske lidelser i gata og datakriminalitet på nettet. Begge deler krever kompetanse og paradigmatiske forståelser som klargjør hva som er politiets rolle og hvordan slike saker skal følges opp.

Aktivt å formulere paradigmer er slik også en måte å utvikle politirollen. Hvis man har en løpende samtale om forståelsen av moralsk ladde saker og på hvilken måte man bør respondere, vil paradigme-lignende fortellinger utkrystallisere seg. Skal disse bli noe mer enn uformelle illustrasjoner av lokale praksiser, kreves det en ledelse som legger til rette for refleksjonsprosessene og gir disse den tyngden de fortjener.

I alle yrker der faglig autonomi eller skjønnsutøvelse står sterkt, vil det finnes motstand mot utvikling av beste praksiser og evidensbasering. Man kan godt se moralsk kasuistikk som et skritt på veien mot uniformering av praksis, men kasuistikken har typisk et lavere generalitetsnivå - den gir beslutningsstøtte i moralsk utfordrende situasjoner, ikke absolutte føringer. Med sin praksisnærhet kan kasuistikken bidra til at man kan arbeide mot en slags «reflektert likevekt» mellom de veloverveide moralske oppfatningene som paradigmene representerer, lover og regler, samt de oppfatninger om politiets arbeid som finnes ellers i samfunnet ${ }^{\mathrm{xvi}}$. En slik bred reflektert likevekt forhindrer at paradigmene blir rene profesjonsinterne anliggender. Det er jo nettopp en styrke ved kasuistikken at den har eksempler i bunnen, og kan inngå i en dialog med andre parter uten omfattende begrepsmessig spesialkunnskap.

\section{b) Når er problemet likt nok paradigmet?}

Gitt at man enes om et paradigme som illustrerer en slags beste praksis for en type politiarbeid: når er eksempel-saken lik nok paradigmet til å bedømmes på samme måte? Dette problemet har dukket opp flere ganger allerede. Hevder man at alle politioppdrag er unike i sterk forstand er kasuistikk umulig. En mer moderat posisjon som synes rimeligere, er at alle oppdrag har særtrekk - men særtrekk gjør ikke at et paradigme blir irrelevant. Spørsmålet er snarere hvilke fellestrekk de har og hvilke særtrekk som utgjør moralsk relevante forskjeller mellom problem og paradigme. Om man kan trekke analoge slutninger, er et spørsmål om skjønn. Vurderingene er altså fortsatt skjønnsbaserte, men innenfor kasuistikken bør vurderingene likefullt basere seg på paradigmets velbegrunnede vurderinger så langt det lar seg gjøre (Baune, 1998, s. 67). 
Ofte handler vi etter intuisjon eller legger «sunn fornuft» til grunn: man gjenkjenner en situasjon og handler omtrent likedan som sist - hvis man da lyktes. Slik heuristikk basert på erfaring, vil i mange tilfeller være et godt nok grunnlag for politiarbeid, men som etisk refleksjon kreves mer enn overfladisk gjenkjennelse. Kasuistikk krever en tilgrunnleggende kunnskap om hvilke moralske egenskaper paradigmet har, og en stadfestelse av at disse i det minste dels også finnes i problemet ${ }^{x v i}$. Kasuistikk er altså ikke taus eller tilfeldig kunnskap, men støtter seg på eksplisitte paradigmer.

I trafikkeksemplene ovenfor inneholdt paradigmet flere etiske hensyn, blant annet lojalitetshensynet til kollegaen, hensynet til tredjeparters trygghet, og hensynet til likebehandling. Hensynene trekker i ulik retning, og man kan tenke seg at de til sammen skaper en resultant utfra graden av risiko fartsovertredelsen utgjør, og graden av følt lojalitet. Man kan se for seg en slags vektskål som tipper den ene eller den andre veien. Kanskje er det ikke så vanskelig for betjentene i paradigmet, ettersom det er en nyansatt kollega som de ikke kjenner så godt, og siden fartsovertredelsen er relativt høy. I Problem 1 gjelder de samme hensynene, men nå er det studenten som er den ferske aktøren i saken. «Resultanten» av hensynene blir dermed annerledes. Samtidig kan man mene at fartsovertredelsen i de to tilfellene er hinsides rommet for å utøve politiskjønn, og at verdikonflikten i Problem 1 kun er et spørsmål om studentens integritet versus politimesterens autoritet - altså et annet sett egenskaper.

Her anes en mulig fordel ved å ha et paradigme som består av flere godt gjennomtenkte eksempler som har familielikhet (Wittgenstein, 1997, § 66-67). Dette gir støtte for bedømmelsen av de etiske hensynene som trekker i ulik retning med ulik styrke. Selv om man mener at de etiske hensynene er annerledes i Problem 1 enn i paradigmet, er det nettopp ved å bryne seg mot paradigmet at man blir klar over særegenheten og kan formulere den. Nær kjennskap til paradigmers moralske struktur gjør også at man blir klar over likheten ved tilsynelatende forskjellige saker. Dette kan i tur gi støtte til avgjørelser i saker der paradigmer mangler. I det minste gir det et utgangspunkt for videre refleksjon.

Hvis likheten er stor nok, er det da moralsk sett påbudt å handle på samme måte i problemet som i paradigmet? Svaret på det er «nei». Likheten mellom problemet og paradigmet gjør at det først og fremst er tillatt og kanskje tilbørlig å handle på samme måte. Det er altså en veiledning som etisk refleksjon gir. Unntaket er skremmebilder. Disse beskriver gjerne forbudte handlinger eller løsninger som virker krenkende, risikofylte eller uhensiktsmessige.

\section{c) Er kasuistikk uttrykk for konservatisme?}

Moralsk kasuistikk fremstår lett som en tilbakeskuende fremgangsmåte: man forsøker jo å sammenligne med hva man har gjort tidligere. Kasuistikken kan slik sett bli konservativ og lite åpen for endringer. Nå har flere hevdet at konservatisme er et trekk ved politikulturen (Reiner, 2010, s. 126 f.), og kanskje en det naturlig all den tid politiets grunnleggende oppgave er å håndheve loven. Men politiet bør heller ikke tviholde på avleggse oppfatninger og måter å håndtere ro og orden på. Å komme i utakt med samfunnet er ødeleggende for politiets evne til å løse samfunnsoppdraget. Blir paradigmene hellige, blir det også vanskelig å forholde seg til nye sosiale problemer som oppstår (Spielthenner, 2016, s. 425). Dette kan være et problem, spesielt i tider der samfunnet blir mer pluralistisk - for en kasuistikk som har ambisjoner utover det lokale, krever konsensus omkring 
paradigmene. Men selv om konsensus er viktig, bør yrkesutøvere selvsagt ikke summarisk følge utdaterte paradigmer. Moralske paradigmer er ikke lover, men prima facie normer, dvs. de er moralske normer som gjelder $i$ utgangspunktet. Det er heller ikke ødeleggende for paradigmet om de ikke følges til punkt og prikke hver gang. ${ }^{\text {xviii }}$

Et sentralt poeng er at når man forholder seg aktivt til mønstereksemplene så «etterprøves» de. Deres normative kraft styrkes eller svekkes. Paradigmene styrkes hvis de oppfattes som konstruktive. Hvis ikke, svekkes de. Bevissthet rundt denne formen for vitenskapelighet er viktig slik at ikke kasuistikken hindrer nytenkning. Noe av styrken som fremheves ved kasuistikk er jo at den gjennom å fokusere på «saken selv» - og ikke for mye på prinsipper og dogmer. Kasuistikken kan skape konsensus på tvers av f.eks. kulturforskjeller og politiske oppfatninger. Dette er et av funnene til Stephen Toulmin (1981) som har benyttet moralsk kasuistikk som arbeidsform innenfor medisinsk etikk. $^{\text {xix }}$

I politisammenheng kan kasuistikken støte på problemer når nye former for kriminalitet oppstår. Slike trender passer ikke nødvendigvis med det paradigmatiske synet på kriminalitet. For eksempel, hvordan bør politiet forholde seg til import av komponenter til syntetiske rusmidler som stadig endrer karakter og slik unngår lovgivningen? Er tradisjonell hjemmebrenning en god analogi? Eller, er phishing på nettet analogt med tidligere tiders telefonsvindel? I hvilke situasjoner blir deep fake et politianliggende? Kanskje trenger man kombinasjoner av paradigmer eller kanskje helt nye paradigmer som med tiden kan danne basis for ny lovgivning (Paulsen, 2019, s. 38).

Sett på avstand vil en godt utviklet kasuistikk være et uttrykk for, og en tolkning av, kulturen man er del av - i dette tilfellet både politikulturen(e) og den mer omfattende kulturen politiet virker innenfor. Som påpekt av Arras (2017, s. 54), kan kasuistikken ha status som en anskueliggjøring av en slags ortodoksi $\mathrm{i}$ en gitt periode, innenfor et visst felt ${ }^{\mathrm{xx}}$. For å tenke i tråd med Thomas Kuhn (2012), vil det på et tidspunkt oppstå anomalier/avvik som er vanskelige å håndtere, og kanskje må politiets rolle i samfunnet revurderes. At politiets grad av bevæpning, måten politiet skal operere i rusfeltet på, og i hvilken grad «sivile» skal kunne ivareta tradisjonelle politioppgaver diskuteres, kan være symptomer på en krise, men det kan også utgjøre en høyst betimelig utvikling og nytenkning innenfor en profesjon.

Samtidig bør ikke kasuistikken bli for fleksibel: Det vil si at man har så mange paradigmer og varianter å velge $\mathrm{i}$ at man alltid kan finne et som passer og som kan begrunne det man ønsker å gjøre (Pascal, 1987). Kasuistikken kan da fort bli et redskap for falsk rettferdiggjøring eller «moralsk nøytralisering» (Sykes \& Matza, 1957). Igjen er det et poeng at man tar moralsk kasuistikk for det den er: nemlig noe som gir prima facie føringer for hva man bør gjøre, den skal ikke unnskylde malpraksis. Kasuistikken gir et utgangspunkt, men krever at man reflekterer etisk og at analogislutningene synes rimelige - også for andre.

\section{Mønstereksempler fra politipraksis}

Det er ingen mangel på meninger om hvordan politiarbeid skal gjøres, hverken fra publikum eller internt i politiet. I politiet sirkulerer mer eller mindre paradigmatiske fortellinger rundt om i politibiler, på piketten og ellers hvor politifolk møtes. Politiet har også prosedyrer for mange ting, fra 
oppstilling på dør til avhørsteknikker og livredning i vann. Man øver på gjennomføring av oppdrag og fokuserer på ferdigheter i forhold til godkjenning av innsatspersonell på ulike nivåer. Slik trening fokuserer på taktiske og tekniske prosedyrer og operativ kommunikasjon ${ }^{\mathrm{xxi}}$. At etikkens rolle ved politiarbeid tematiseres i liten grad, er det mange grunner til:

For det første: I politiet står tradisjonelt juridisk og teknisk/taktisk kompetanse sterkt i forhold til samfunnsfag/humaniora. Sunn fornuft og erfaringsbasert politiskjønn ses ofte på som tilstrekkelig, og taus kunnskap har blant mange forrang foran akademisk kunnskap (Gundhus, 2013). Den tause kunnskapen er dels eksklusiv og forstås ikke før man er innenfor politifeltet og har politiets unike innsikt i samfunnets «bakside». En slik moralsk taushet bidrar til å gjøre den enkelte betjents politiskjønn suverent i større grad. Dette gir dels en profesjonell frihet, dels tjener det til å opprettholde et hierarkisk system. Denne friheten innebærer at man kan regulere innsatsen etter dagsform, ressurser, og alle de momentene som virker inn på skjønnsutøvelsen (Heivoll, 2018, s. 249 ff). Men fritt skjønn som ideal bidrar lett til profesjonell middelmådighet, ettersom det inviterer til både slagsider og «støy» i tjenesteutøvelsen (Kahneman, Sibony \& Sunstein, 2021). Andre lærer dessuten bare indirekte og tilfeldig av ens arbeid. Kasuistisk arbeid som er konsensusorientert og skriftliggjort, skaper mer likhet i tjenesten, men gir også argumenter for endring. Kasuistisk metode utfordrer påstanden om at nær sagt alle politioppdrag er unike. ${ }^{\text {xii }}$ Når skjønn utøves, er det riktignok rom for ulik behandling, men i offentlig tjenesteutøvelse bør ikke handlingene ha karakter av tilfeldighet. Det skal være likhet for loven, og skjønnsutøvelsen bør ikke undergrave denne likheten, selv om man ikke kan forlange millimeterpresisjon i moralske spørsmål (Aristoteles, 2013, s. 1094b). Samtidig må man kunne vurdere relevansen til forskjeller. Profesjonalitet i vid forstand kan bare vokse frem i et fagfellesskap der man aktivt diskuterer hva som er beste praksis. Dette krever åpenhet, det krever at man bygger yrkesetisk kompetanse, og det krever egnede fora til å bedrive slik refleksjon.

For det andre står makt ofte i et problematisk forhold til etikk. Politiarbeid har ofte en reaktiv karakter - politiet tilkalles og rydder opp så raskt som mulig utfra de forutsetningene som eksisterer. Man gjør det som må gjøres, og skjønnet er da «smalt» (Kleinig, 1996, s. 84). I praksis er det da lett å se et motsetningsforhold mellom politiets maktutøvelse og etikk, mellom handlekraft og refleksjon. Men det er kanskje nettopp i akutte maktutøvelseskontekster at det gjelder å ha en etisk beredskap - ha tenkt på forhånd, slik at man har klart for seg begrensningene og mulighetene den etiske refleksjonen angir. Gjennomdrøftede paradigmer kan da være en nyttig ressurs, men de må både være kjente og anerkjente.

For det tredje, det finnes en sterk grad av lojalitet blant betjenter og motvilje mot å diskutere og spesielt rapportere tjenestehandlinger (Granås, Lindesteg \& Otterstad, 2015; Holgersson, 2019; Trædal 2015). Ettersom mye politiarbeid er uoversiktlig og innebærer beslutninger under usikkerhet, er det dermed ikke urimelig at man ønsker å opprettholde et stort rom for skjønnsutøvelse. Innspill fra personer som ikke var til stede i situasjonen, oppfattes lett som utidig kritikk. Vurderinger av sakens moralske sider - $\mathrm{i}$ ettertid - innebærer slik fort en form for bedrevitenhet. Hvem har bestemt at dette er riktig? Spesielt hvis retningslinjer kommer fra høyere hold, er skepsisen nærliggende (Gundhus, 2013; Wathne, 2015, s. 309 ff.). Men kasuistikk inviterer til praksisnærhet. Som en form for erfaringslæring, bør den organiseres ovenfra, men den kan ikke lykkes uten engasjement nedenfra. 
Kasuistisk-lignende refleksjon finnes allerede i politiet, som i andre profesjoner der moralske konflikter ofte oppstår. Men den foregår bare i liten grad systematisk. Derfor kan man ikke forvente å finne det vi her har kalt paradigmer, selv for mange av de vanligste situasjonene politiet befinner seg i. Normative støttepunkter finnes, Politiloven/-instruksen gir f.eks. også normer for politiarbeid, uten at disse er eksemplifisert i form av paradigmer. Det finnes gode lokale initiativer som «Rettferdig politiarbeid» (Grindem, 2019) i Oslo, som arbeider med en prosessrettferdig tilnærming for politiarbeid i områder der man opplever utfordringer. Et lignende initiativ hadde man tidligere i aktivt oppsøkende politiarbeid, «trygghet og tillit» i Drammen (Kolstad, 2010). Den innflytelsesrike dialogmodellen bør også nevnes her, der man unngår eskalering i møtet med gjengkriminalitet gjennom «å starte og slutte med et håndtrykk» (Jensen \& Stubberud, 2011). Disse initiativene springer ut fra moralske utfordrende kontekster der mistilliten er gjensidig. Dette er situasjoner der det er spesielt viktig å finne en forutsigbar linje å forholde seg til, finne paradigmer som angir hva man bør gjøre og hvordan man bør gjøre det.

I avhørssammenheng er KREATIV-metoden i dag den foretrukne fremgangsmåten (Bjerkenes \& Fashing, 2017; Fashing \& Rachlew, 2009), en metode som også har vunnet gehør internasjonalt, og som avløser en strategi der det å fremkalle tilståelser var målet. Denne nye avhørsmetodikken er ikke en fortelling, men den fremmes og forsvares enklest gjennom eksempler som viser hvordan man går glipp av vesentlige momenter ved å legge press på den avhørte, eller at justismord skjer på grunn av en mislykket strategi. Det har, kan man si, skjedd et «paradigmeskifte» på dette feltet. Asbjørn Rachlews inngående erfaringer både med det nye og det gamle paradigmet gir et godt eksempel på hvordan endringer kan skje, og hvor krevende det kan være (Rachlew, 2009, s. i-iii), både individuelt og for politietaten.

Man har også retningslinjer for andre typer politiarbeid, f.eks. bekymringssamtaler, men retningslinjene er svært generelle. I denne sammenhengen har de tradisjonelle fortellingene om «krimtrappen» eller «rustrappen» hatt paradigmatisk karakter. Disse var detaljert fremstilt i tidligere veiledere, men finnes kun i stilisert utgave i de nyere versjonene (Politidirektoratet, 2011). Som fortellinger har de mistet noe av sin normative kraft, selv om de har vært velmente nok. Paradigmer krever mer eksplisitte formuleringer som fremmer klarere føringer i moralske spørsmål. Man kan heller ikke bare postulere at paradigmet er korrekt på grunnlag av en maktpersons, eller en liten gruppes intuisjoner. Spielthenner (2016, s. 425) advarer mot lemfeldighet på dette punktet:

Some casuists adopt an even more subjectivist standpoint by holding that paradigm cases should be decided on the basis of the casuist's moral intuitions. But critics have rightly observed that 'our intuitions have often been shown to be wildly wrong, if not downright prejudicial and superstitious'. In light of these comments, I think it is fair to say that whatever the source of justification, casuistic arguments are often epistemically defective because there is not sufficient warrant for the decision about the paradigm case.

Dette gir et argument for kasuistikk som et bredt felleskapsprosjekt, og videre et argument for viktigheten av å anerkjenne at paradigmer er rådende hypoteser innenfor en kultur, som er eksplisitte og åpne for kritikk. A stadfeste hvilke verdier og hvilket faktagrunnlag som ligger til grunn for paradigmene er avgjørende når man arbeider med moralsk kasuistikk.

Til slutt skal nevnes at man har ansporende og skremmende eksempler som sirkulerer som frittstående politifortellinger. De fleste betjenter har hørt historien om den bilen man tilfeldigvis stanset 
i en trafikkontroll som har bagasjerommet fullt av narkotika (dette kan fungere som et argument for en mistankebasert stopp og sjekk-praksis). De fleste kjenner også historien om de som ble møtt med våpen $\mathrm{i}$ 11. etasje $\mathrm{i}$ høyblokka mens våpnene lå nedlåst i politibilen (et argument for permanent bevæpning). Slike fortellinger fortelles og gjenfortelles og benyttes som argumenter med tyngde. Det viser bare at paradigmer lar seg skape og spre. Men anekdoter bør ikke bli paradigmer kun fordi de fortelles og gjenfortelles.

Samling av paradigmatiske fortellinger om imponerende, om godt nok, og om uakseptabelt politiarbeid kan danne grunnlag for en åpen og akselerert erfaringslæring der politibetjenter forholder seg aktivt til andres erfaringer og kan nyansere og utfordre disse gjennom egne erfaringer. Slik kan kasuistikk bli et nyttig verktøy for etisk refleksjon, ettersom det bringer stor grad av saklighet og faglighet inn i diskusjonen om politiarbeid. Riktignok kan kasuistikk oppleves som en utfordring for den profesjonelle autonomien, men denne oppveies av den støtten godt tilrettelagte normative diskusjoner gir for skjønnsutøvelse. Dette er en prosess som krever tid og rom til å arbeide systematisk med eksempler over tid, og at paradigmene forankres bredt. Dette er heller ikke et arbeid man kan håpe på å bli ferdige med. Det er også spesielt viktig i en tid med politireformer og oppkomst av nye former for kriminalitet. Kasuistikk bør være en del av beredskapen.

\section{Forfatterbiografi}

Jens Erik Paulsen er professor ved Politihøgskolen, avd. Oslo. Hans forskningsinteresser omfatter refleksjonsmetodikk og ulike profesjonsetiske problemstillinger, samt bruk og kvalitetssikring av teknologi. Han er Dr. art (filosofi) fra Universitetet i Oslo, og har tidligere arbeidet ved Universitetet i Oslos Etikkprogram og Senter ved medisinsk etikk ved UiO.

\footnotetext{
«Pikett» er blant annet betegnelsen på politiets pauserom (Finstad, 2000, s. 35-36; Waddington, 1999) Waddington benytter begrepet «canteen culture».

ii https://www.politiet.no/globalassets/dokumenter/pod/rapporter/klager-pa-politiet-2020.pdf

iii Når slike legges til grunn for refleksjon i undervisning kalles dette gjerne «case-basert» undervisning. Dette til forskjell fra en kasus, som er betegnelsen på en bøyningsform innenfor grammatikken.

iv Paradigme er et gresk ord som betyr 'mønster'.

v Erfarne politibetjenter er «håndverkere» og deres tjenestehandlinger fungerer didaktisk som varige «modeller» for mindre erfarne kollegaer (Finstad, 2000, s. 162 ff.).

vi Ruyter (1998) fremholder at paradigmatiske eksempler både kan være illustrerende og ansporende, og kan omhandle både det hverdagslige og ekstremsituasjoner.

vii Det gamle paradigmet kan fortsatt bidra til å styrke situasjonsforståelsen, men man vil ikke handle i tråd med paradigmets anbefaling (handlingsskjønnet).

viii Dette gjelder f.eks. ransaking kun ved mistanke om besittelse av brukerdoser av narkotika - eller adgang til bagasjerom i bil for å kontrollere at varseltrekant er på plass.

ix For en diskusjon av studentdilemmaer, se Paulsen (2021).
} 
x Kasuistikken er slik en «intuitiv» måte å bedømme saker med røtter i både common sense og $\mathrm{i}$ common law-tradisjonen (Arras, 2017; Halvorsen, 1998).

xi Kasuistikk har visse fellestrekk med såkalt Recognition-Primed Decision making, se Klein (2009, s. 91).

xii It should be noticed that 'case' can refer to an individual case (casuistry becomes then reasoning from particular to particular), but it commonly refers to a class of cases (Spielthenner, 2016, s. 419).

xiii F.eks. Fritz Moen-saken som er et mye benyttet skrekkeksempel på etterforskning som også er blitt utredet offentlig (NOU 2007: 7), rettsaken mot Eirik Jensen og det etterfølgende rapporten om politikorrupsjon (Politidirektoratet, 2021) som har satt søkelys på kultur, notoritet og korrupsjon, og ikke minst 22. juli-rapporten som satte søkelys på organisering og beredskap (Gjørv, 2012).

xiv Disse kildene minner om komponentene som bidrar til utviklingen av dømmekraft ifølge Christoffersen $(2011$, s. 88).

xv Dette er også en type diskusjon som går langt tilbake i tid, ikke bare i kasuistikken, men også når det gjelder autoritet generelt (Aristotle, 1994, 100b121-103)

xvi Se særlig Ruyter (1995, s. 175-179). Å tillate diskusjon av prinsipper inn i kasuistikken kan dessuten være helt greit (Childress, 1997). Prinsipper blir en slags essens av de større fortellingene, men prinsippene bør likevel forstås og tolkes gjennom eksempler på yrkesut $\varnothing$ velse. Begrepsbruken videre i denne passasjen stammer fra Rawls (1971, s. 48-51): «reflective equilibrium», "considered judgements».

xvii Det er et for strengt krav at alle hensyn skal være like, og det er som regel et for veikt at bare ett av mange hensyn er like (Baune, 1998, s. 54).

xviii Samtidig er det viktig at man tar paradigmene seriøst nok. Historisk sett har kasuistikk hatt en viktig funksjon i sosiale brytningstider, samtidig som den har blitt kritisert for å være for fleksible (Jonsen \& Toulmin, 1988).

xix Toulmins eksempel omhandler bruk av mennesker i medisinsk og psykologisk forskning, der beslutningstakerne hadde ulik religiøs og faglig bakgrunn.

xx Altså som et slags kuhnsk paradigme (Kuhn, 2012, s. 43 ff.)

xxi De aller fleste politioppdrag har kommunikasjon som viktigste maktmiddel (NOU 2017: 9).

xxii Se f.eks. Aas (2009, s. 8): «Det åpne, uforutsigbare og ubestemte ved politioppdrag», etc. 


\section{Referanser}

Aristoteles. (2013). Den nikomakiske etikk. Vidarforlaget.

Aristotle. (1994). Topics. Hentet fra http://classics.mit.edu/Aristotle/topics.1.i.html

Arras, J. D. (2017). Getting down to cases. I J. F. Childress \& M. Adams (Red.), Methods in bioethics. The way we reason now, 45-74. New York: Oxford University Press.

Baune, Ø. (1998). Hvorfor er kasuistisk moral ikke til å komme forbi? I J. Wetlesen (Red.), Hva er kasuistikk? Om moralsk laering og refleksjon i tilknytning til forbilder og eksempler, Bind 3, 40-79. Universitetet i Oslo.

Bjerkenes, O. T. \& Fashing, I. (2017). Etterforskning. Prinsipper, metoder og praksis. Fagbokforlaget.

Carson, S. G., Kosberg, N., Skauge, T. \& Laurberg, T. (2015). Etikk for beslutningstakere. Cappelen Damm Akademisk.

Childress, J. F. (1997). Narrative(s) versus Norm(s). A Misplaced debate in bioethics. I H. L. Nelson (Red.), Stories and their limits. Narrative approaches to bioethics. Routledge

Christoffersen, S. A. (2011). Profesjonsetikk. Om etiske perspektiver i arbeidet med mennesker (2. utg). Universitetsforlaget.

Fashing, I. \& Rachlew, A. (2009). Investigative interviewing in the Nordic region. I T. Williamson, B. Milne \& S. P. Savage (Red.), International Developments in Investigative Interviewing. Cullompton: Willan.

Finstad, L. (2000). Politiblikket. Pax Forlag A/S.

Gjørv, A. B. (2012). Rapport fra 22. juli-kommisjonen : oppnevnt ved kongelig resolusjon 12. august 2011 for å gjennomgå og trekke loerdom fra angrepene på regjeringskvartalet og Utøya 22. juli 2011. Avgitt til statsministeren 13. august 2012 (Norges offentlige utredninger). Departementenes servicesenter. Informasjonsforvaltning.

Granås, L., Lindesteg, R. \& Otterstad, B. (2015). "A sitte stille i båten". En kvalitativ studie av hvordan fryktkultur beskrives og oppleves i politiet - og hva fører den til? (Master). Høgskolen i Hedmark, Hamar.Hentet fra https://brage.inn.no/inn-xmlui/bitstream/handle/11250/283069/GranLindOtter.pdf? sequence=1\&isAllowed=y

Grimen, H. (2008). Profesjon og kunnskap. I A. Molander \& L. I. Terum (Red.), Profesjonsstudier, 71-86. Universitetsforlaget.

Grindem, K. (2019). Slik skal Oslo-politiet bygge tillit med minoritetsungdom. Politiforum.

Gundhus, H. I. (2013). Experience or knowledge? : perspectives on new knowledge regimes and control of police professionalism. Policing: Journal of Policy and practice, 7(2), 178-194. http://doi.org/10.1093/police/pas039

Habermas, J. (1987). The Theory of Communicative Action. Cambridge: Polity Press

Halvorsen, M. (1998). Moralsk kasuistikk og juridisk presedenstenkning - hva er likt og hva er forskjellig? I J. Wetlesen (Red.), Hva er kasuistikk? Om moralsk loering og refleksjon i tilknytning til forbilder og eksempler, Bind 3, 80-94. Universitetet i Oslo.

Heivoll, G. (2018). Lovens lange arm? En studie av politibetjenters rolle som rettshåndhevere $i$ den norske demokratiske rettsstaten. Cappelen Damm Akademisk.

Holgersson, S. (2019). Whistleblowing within the Swedish Police. Nordisk politiforskning, 6(1), 24-45. https://doi.org/10.18261/issn.1894-8693-2019-01-04

Hulst, M. v. (2013). Storytelling at the police station. The Canteen Culture Revisited. British journal of criminology, 53, 624-642. https://doi.org/10.1093/bjc/azt014 
Justisdepartementet. (1986). Straffeprosessloven (Lov om rettergangsmåten i straffesaker, (rettet 23.04.2021).

Justis- og beredskapsdepartementet. (2016). Oppdragsdokument til POD - Gjennomføring av Ncerpolitireformen.

Jensen, E. \& Stubberud, R. (2011). Alt starter og avsluttes med et håndtrykk. Dialog med gjengstrukturer, erfaringer, resultater og råd. Politiet. https://phs.brage.unit.no/phs-xmlui/bitstream/handle/11250/174892/bachelor Isefjaer.pdf?sequence $=1 \&$ isAllowed $=\mathrm{y}$

Jonsen, A. R. \& Toulmin, S. (1988). The Abuse of Casuistry: A History of Moral Reasoning. University of California Press.

Kahneman, D., Sibony, O. \& Sunstein, C. R. (2021). Noise. A flaw in human judgment. Little, Brown Spark.

Kirkebøen, G. (2013). Kan vi stole på fagfolks skjønn? I A. Molander \& J.-C. Smeby (Red.), Profesjonsstudier II. 27-43. Universitetsforlaget.

Klein, G. (2009). Streetlights and Shadows: searching for keys to adaptive decision making. The MIT Press.

Kleinig, J. (1996). The ethics of policing. Cambridge University Press. https://doi.org/10.1017/CBO9781139172851

Kolstad, S. (2010). Prosjekt trygghet og tillit. Politiforum. https://www.politiforum.no/buskerudingelin-killengreenm-nyheter/prosjekt-trygghet-og-tillit/103373

Kuhn, T. S. \& Hacking, I. (2012). The structure of scientific revolutions (Fourth edition). The University of Chicago Press. https://doi.org/10.7208/chicago/9780226458144.001.0001

Kvalnes, Ø. (2012). Etikk og samfunnsansvar. Universitetsforlaget.

NOU 2007: 7. Fritz Moen og norsk strafferettspleie. Departementenes servicesenter, Informasjonsforvaltningen. Hentet fra https://www.regjeringen.no/no/dokumenter/nou-2007$\underline{07 / \mathrm{id} 473769 /}$

NOU 2013: 9. Ett politi - rustet til å møte fremtidens utfordringer. Oslo: Departementenes servicesenter, Informasjonsforvaltningen.

NOU 2017: 9. Politi og bevcepning — Legalitet, nødvendighet, forholdsmessighet og ansvarlighet. Departementenes servicesenter, Informasjonsforvaltningen.

Pascal, B. (1987). Provinsialbrevene. Aschehoug.

Paulsen, J.E. (2019). Holdninger til høyteknologi. I I. M. Sunde \& N. Sunde (Red.), Det digitale er et hurtigtog - Om politiet $i$ et digitalisert samfunn. Oslo: Fagbokforlaget.

Paulsen, J. E. (2019). Holdninger til høyteknologi. I I. M. Sunde \& N. Sunde (Red.), Det digitale er et hurtigtog - Om politiet $i$ et digitalisert samfunn, 23-49. Fagbokforlaget.

Paulsen, J.E. (2020). Verdibasert refleksjon i planlegging og erfaringslæring. Nordisk politiforskning, 7(1), 61-76. https://doi.org/10.18261/issn.2703-7045-2020-05

Paulsen, J. E. (2021). "Det er ikke nødvendigvis den største takhøyden...". Tidsskrift for professionsstudier, 17(32), 78-88.

Politidirektoratet. (2011). Veileder for politiets bekymringssamtale. Dialog for ansvar og positiv endring.

Politidirektoratet. (2021). Politikorrupsjon. Lederskap, risikoerkjennelse og loering. Oslo. Hentet fra https://www.politiet.no/globalassets/dokumenter/pod/rapporter/rapport-fra-evalueringsutvalget.pdf 
Rachlew, A. (2009). Justisfeil ved politiets etterforskning: Noen eksempler og forskningsbaserte mottiltak [Doktoravhandling. Det juridiske fakultet, Universitetet i Oslo]. UiO Unipub.

Rawls, J. (1971). A Theory of Justice. The Belknap Press of Harvard University Press.

Reiner, R. (2010). The Politics of the Police (4. utg.). Oxford University Press. https://doi.org/10.1093/he/9780199283392.001.0001

Ruyter, K. W. (1995). Kasuistikk som saksbasert problemløsning i medisinsk etikk (Dr.philos). Universitetet i Oslo.

Ruyter, K. W. (1998). Om bruken av forbilledlige og ekstreme eksempler i moralske resonnementer. I J. Wetlesen (Red.), Hva er kasuistikk? Om moralsk loering og refleksjon i tilknytning til forbilder og eksempler, Bind 3, 127-151. Universitetet i Oslo.

Smeby, J.-C. (2013). Profesjon og ekspertise. I A. Molander \& J.-C. Smeby (Red.), Profesjonsstudier II, 17-26. Universitetsforlaget.

Spielthenner, G. (2016). The casuistic method of practical ethics. Theor Med Bioeth, 37, 417-431. https://doi.org/10.1007/s11017-016-9382-8

Strong, C. (2013). Casuisty International Encyclopedia of Ethics: Wiley Online Library. https://doi.org/10.1002/9781444367072.wbiee9781444367344)

Sykes, G. M. \& Matza, D. (1957). Techniques of Neutralization: A Theory of Delinquency. American Sociological Review, 22(6), 664-670. https://doi.org/10.2307/2089195

Toulmin, S. (1981). The tyranny of principles. Hastings Center Report, 11, 31-39. https://doi.org/10.2307/3560542

Tranøy, K. E. (1998). Det åpne sinn: Moral og etikk mot et nytt årtusen. Universitetsforlaget.

Trædal, T. (2015). Historiene har blitt kjent, debatten har rast. Finnes det en fryktkultur i politiet? Politiforum.

Waddington, P. A. J. (1999). Police (canteen) sub-culture. An appreciation. British journal of criminology, 39(2), 287-309. https://doi.org/10.1093/bjc/39.2.287

Wathne, C. T. (2015). Som å bli fremmed $i$ eget hus: Politiets opplevelse av mening og motivasjon i lys av nye styringssystemer [Doktoravhandling. Det juridiske fakultet, Universitetet i Oslo]. http://urn.nb.no/URN:NBN:no-56456

Wittgenstein, L. (1997). Filosofiske undersøkelser. Pax Forlag A/S.

Aas, G. (2009). Politiinngrep i familiekonflikter. En studie av ordenspolitiets arbeid med familiekonflikter/familievoldssaker i Oslo [Doktorgradsavhandling. Universitetet i Oslo]. http://hdl.handle.net/11250/174715 